\title{
AN OVERVIEW OF THE AUSTRALIAN BIOMASS RESOURCES AND UTILIZATION TECHNOLOGIES
}

\author{
* Behdad Moghtaderi, Changdong Sheng, and Terry F. Wall
}

\begin{abstract}
Information on Australian biomass resources including bagasse, black liquor from paper pulp production, wood waste and forestry residues, energy crops, crop wastes, food and agricultural wet waste, and municipal solid wastes is provided in the review. The characteristics of the Australian biomass are typical of those of other countries, i.e., high moisture and volatile matter, low heating value and density, and low sulfur and nitrogen content, but high $\mathrm{Ca}$ and $\mathrm{Mg}$ for woody biomass. The characteristics influence biomass utilization. Biomass is used extensively at present within Australia, primarily for domestic heating, as bagasse in the sugar industry, and for electricity generation. Biomass usage for electricity generation is increasing and is expected to reach $5.2 \mathrm{Mt} / \mathrm{year}$ by 2019-20. Exports, as wood chips, are approximately $10 \mathrm{Mt} / \mathrm{year}$ in 2000-01. Forestry residues have been estimated to be $23 \mathrm{Mt} /$ year. Current technologies that utilize biomass in Australia include those for electricity and heat by direct combustion, cofiring with coal and fluidized bed combustion), for biogas generation (from landfills, and aerobic digestion, and as bio-liquids. Related to bio-liquid fuels, ethanol production from molasses and wheat is making progress. The resultant ethanol is used as a petrol extender, and a bio-diesel process is under development.
\end{abstract}

Keywords: Biomass, Australian resources, Utilization technologies

Contact information: Discipline of Chemical Engineering, School of Engineering, Faculty of Engineering \& Built Environment, The University of Newcastle, Callaghan, NSW 2308, Australia; *Corresponding author: Behdad.Moghtaderi@newcastle.edu.au

\section{INTRODUCTION}

Coal energy is facing increasingly heavy pressure related to concerns of global warming and reducing greenhouse gas $\mathrm{CO}_{2}$ emission. One of the biggest contributors to greenhouse gas emissions is fossil fuel coal (Davidson 1999; Werther et al. 2000; Sami et al. 2000; Williams et al. 2001). Among the nations that use this fossil fuel, Australia has a major dependence on coal energy and in addition is the preeminent coal exporter. Domestically, coal supplies a $41 \%$ share of primary energy consumption and a $79 \%$ share of electricity generation, and coal will continue to be a crucial part of the energy mix in the foreseeable future (Dickson et al. 2002). However, due to environmental concerns associated with greenhouse gas emissions and global warming, the reliance on coal is on a decline despite the availability of coal and efforts being directed towards clean coal technologies (Dickson et al. 2002). The implication is that other energy resources are required to fill the gap. Biomass is expected to play a significant role in this context 
because of its $\mathrm{CO}_{2}$ neutrality and renewable nature, as well as its relatively low cost and availability.

Currently, Australia obtains $5.9 \%$ of its primary energy requirements from renewable resources, of which biomass together with biogas, is predominant and holds a $78.3 \%$ share. About $4.5 \%$ of the primary energy consumption in Australia is from biomass, and this percentage is expected to increase to 4.8\% in 2019-20 (Dickson et al. 2001). Of this, nearly $2.0 \%$ is in the form of bagasse (cane residue used in the sugar industry), and $2.8 \%$ in the form of firewood (Eucalyptus and pine used for domestic heating) and wood waste (both soft- and hard-woods such as pine and Eucalyptus, respectively used in the wood products industries) (Bush et al. 1997). Biomass has the potential to be an increasingly cost competitive renewable energy source in Australia, and still to make a valuable contribution to the overall energy system mainly because of its very low price and the fact that it is renewable. There is still considerable scope for making better use of the existing biomass energy supplies and also for developing new supplies.

Biomass is particularly well positioned to play a major role in Australia's effort to reduce greenhouse emissions. Following the government's Mandatory Renewable Energy Target (AGO 2003) adopted on April 1, 2001, the role of renewable energy, mainly biomass, in electricity generation has substantially increased. The energy target requires electricity retailers and large electricity purchasers to source an additional $2 \%$ of their electricity from renewable energy sources by 2010. As a result, the market share of electricity generation for coal is anticipated to shrink from 79.3\% (1998-99 data) to $71.1 \%$ by $2019-20$ while the share of biomass will is expected to rise to about $2.0 \%$ from its current $0.6 \%$ level (Dickson et al. 2001). The present review provides an overview of the Australian biomass resources and utilization technologies in an attempt to promote and facilitate the use of biomass in the energy mix of Australia.

\section{BIOMASS RESOURCES IN AUSTRALIA}

\section{Background}

Biomass is a natural resource. Biomass refers to materials derived from photosynthesis that are not fossilized, such as wood from forest, residues from agricultural and forestry processes, and industrial, human or animal wastes. Australia has a substantial biomass resource, which could provide feedstock for substantial biomass energy and chemical and chemicals industries. The biomass resources that are considered here are the eligible biomass resources under the Renewable Energy (Electricity) Act 2000 (ORER, 2000):

- Bagasse

- Black liquor from paper pulp production

- Wood wastes and forestry residues

- Energy crops

- Crop wastes

- Food and agricultural wet waste

- Municipal solid waste (MSW) 
Note that MSW is predominantly biomass resources and may also have $30-40 \%$ fossil fuel-based hydrocarbons. Therefore, it is also included here.

It must be highlighted that Australia has substantial resources of biomass and wastes. However, it is not easy to estimate the potential amount of all these biomass resources available for utilization, mainly because of wide distribution of these resources across the country, difficulty in biomass collection, species classification and inaccuracy of availability estimation methods (i.e., calculation). The available data on Australia's biomass resources are summarized in Table 1, which is reported based on the amount (Mt/year), or energy production (PJ/year), or potential electricity capacity (MW), or electricity generation $(\mathrm{GWh} /$ year). Each resource is discussed in more detail in the following sections.

Table 1. Summary of the Main Biomass Resources in Australia

\begin{tabular}{|l|c|c|c|c|l|}
\hline Resource & $\begin{array}{c}\text { Amount } \\
\text { (Mt/year) }\end{array}$ & $\begin{array}{c}\text { Energy } \\
\text { (PJ/year) }\end{array}$ & $\begin{array}{c}\text { Electricity } \\
\text { capacity (MW) }\end{array}$ & $\begin{array}{c}\text { Electricity } \\
\text { Generation } \\
\text { (GWh) }\end{array}$ & Reference \\
\hline Bagasse & 10.6 & 100 & 1000 & 4,000 & REM,1999 \\
\hline Cane trash & 9.25 & - & - & - & \\
\hline Black liquor & $0.25^{[a]}$ & - & 49 & 90 & REM,1999 \\
\hline Wood wastes & 6.9 & 120 & - & 10,000 & REM,1999 \\
Forest wastes & 23 & - & 1,500 & - & RIRDC, 2002b \\
\hline Crop wastes & $44^{[b]}$ & - & - & - & REM,1999 \\
\hline Wet waste & $1.8^{[a]}$ & - & 200 & - & \\
\hline MSW & 8.7 & - & 330 & - & Glover, 2002 \\
C\&l & 10.3 & - & 400 & - & \\
C\&D & 13.5 & - & 200 & - & ERDC, 1994 \\
\hline Energy crop & & - & - & - & \\
Cereals & 30 & - & - & - & \\
others & 8 & - & &
\end{tabular}

a. Estimated value based on reported electricity capacity or generation

b. Estimated from the reported in-field agriculture resources reduced by cane wastes

c. Potential energy crops, but agroforestry crops not included.

\section{Bagasse and Cane Trash}

Bagasse is the residual fibre waste from raw sugar processing. It is currently the largest source of renewable energy after hydroelectric, and provides 90 Peta Joules (PJ), or about $2 \%$ of Australia's total primary energy demand (Bush et al. 1997). Bagasse has the advantage over some other forms of biomass (such as woody weeds or forestry thinnings) in that the sugar processing requires the bagasse to be brought to a central location at the mill, so there are no additional transport costs. Bagasse is actually and potentially a major source of biomass energy in Australia, as it can be used as boiler feedstock to generate steam for processing heat and electricity as well. The steam raised from bagasse is used to work the machines that shred and crush the cane, for processing heating, and increasingly to cogenerate heat and electricity. The Australian bagasse cogeneration industry is already quite well developed and mature. Bagasse is available for about half of each year (June to November) from the 25 sugar mills in the State of Queensland (Qld), 3 in the State of New South Wales (NSW) and 1 in the State of Western Australia (WA). These mills have an installed electricity-generating capacity of 
about $250 \mathrm{MW}$, fueled almost entirely with bagasse in cane crush season and cofiring other biomass such as wood wastes in non-crush season (Redding Energy Management, 1999). However, the bagasse resource could potentially supply a much greater capacity. Sugar Research Institute estimated that 10.6 million tonnes (Mt) are available annually, equivalent to $100 \mathrm{PJ}$. This could fuel $1000 \mathrm{MWe}$ of capacity, producing around 4000 GWh/year (Redding Energy Management 1999).

Cane waste is comprised of the leaves and tops of the sugar cane plant. This material is not milled for sugar extraction, and in the past, was burnt in the fields either prior to or after the cane had been harvested. Research has indicated that a typical sugar cane crop, when harvested as green or unburnt cane, is composed of $75 \%$ sugar cane stalk and 25\% leaves and tops (Sunshine Electricity 2002). This waste provides a huge potential fuel resource. Considering an average harvest of $37 \mathrm{Mt}$ of cane per year for the five years from 1994 to 1998 (RIRDC 2002a), it is estimated that around 9 Mt cane waste per year is produced in Australia. Technologies have been developed in NSW and QLD for harvesting the cane trash (Burnard 2002) so as to use it as fuels for cogeneration. For example, in a proposed project, Sunshine Electricity proposes to develop a cogeneration plant adjacent to the Broadwater Sugar Mill that is fueled with bagasse blended with sugar cane waste and will be using annually up to 250,000 tonnes of bagasse and 230,000 tonnes of cane leaves and cane trash. (Sunshine Electricity 2002).

\section{Black Liquor from Paper Pulp Production}

Black liquor is produced as a combustible by-product of the paper and pulp making processes. In Australia, the available black liquor resource is already effectively utilized on-site for cogeneration of electricity and processing steam. Waste wood and coal are also commonly used in addition to the black liquor. Currently, $0.15 \mathrm{Mt}$ of black liquor is produced per year with a total capacity of $49 \mathrm{MW}$, which is equivalent to around $90 \mathrm{GWh}$ electricity and processing heat (Redding Energy Management 1999). There is still a potential capacity of black liquor from new paper pulp plants, which is expected also to be used for on-site cogeneration. About 20\% more capacity is anticipated to come on-line in the next decade, primarily using the conventional combustion-based strategies rather than gasification strategies.

\section{Wood Waste and Forestry Residues}

Australia has $1,581,000 \mathrm{~km}^{2}$ forest area. Over $17 \mathrm{Mt}$ of products are produced annually from forests and plantations across Australia, of which 6-7 Mt is sold as firewood in the domestic market for home and industrial use (Driscoll 2000) and $10 \mathrm{Mt}$ is exported in the form of wood chips (Yainshet 2002). The huge amount of forest residues and wood waste generated from forestry and plantation industry is believed to be sufficient to meet the federal government's 2\% renewable energy target (Redding Energy Management 1999). Although there are a few plants in Australia generating electricity from resources such as sawdust at sawmills, the current level of electricity production from forestry residues and wood waste is not significant at all.

Australian sawmills only utilize $45 \%$ of the wood. Of the remaining off-cuts, $30 \%$ is used to produce woodchips, and the rest is sawdust and chip rejects. The only current use for this is in the horticultural industry. Australia produces 1.25 million tonnes of 
sawmill waste per year, and many mills pay to have this removed. Timber residues from sawmills and from material that is not chipped for export or used for board products is estimated to be equivalent to about $120 \mathrm{PJ} / \mathrm{yr}$ (Redding Energy Management 1999). It is equivalent to about $6.9 \mathrm{Mt}$ wood waste per year. At a conversion efficiency of $30 \%$ this would generate about $10,000 \mathrm{GWh}$ of electricity annually. However, in practice only a fraction of this resource could be economically used for electricity generation.

The ERDC report estimated total forestry residues at 23 million tonnes per year. It was estimated that up to $1500 \mathrm{MW}$ of capacity could be installed to utilize this resource (nominally comprised of $150 \times 10 \mathrm{MW}$ projects) (Redding Energy Management 1999). The practice, however, is not sustainable at the current rate, as resources are anticipated to decline within a timeframe of 100-150 years. Innovative harvesting practices are being researched in order to extend the sustainability of forestry residues utilization. One of the more interesting developments in this context is the research activities being conducted as part of the "Joint Venture Agroforestry Program (JVAP)", a partnership among Rural Industries Research \& Development Corporation, Forest and Wood Products Research \& Development Corporation, and Land and Water Australia (RIRCD 2002c). The idea is the incorporation of trees into a farming system. While for farmers, tree growing boosts their productivity and offers an additional source of income, processors benefit from a more sustainable source of timber with an estimated timeframe of several hundreds of years (RIRCD 2002c).

\section{Energy Crops}

Energy crops refer to biomass (e.g., planted wood sugar cane, corn, wheat, sorghum, etc.) planted specially for direct utilization as energy fuel (i.e., power generation) or as feedstock for production of biofuels (e.g., biodiesel, bioethanol, biomethanol, etc.). There is widespread semi-commercial scale trialing of this resource overseas, especially for power generation, such as coppicing willow, switchgrass, and miscanthus in the UK, and switchgrass in the USA. In Australia, growing energy forestry crops on a large scale has received renewed interest, mainly in woody biomass, but not currently for electricity generation. The Commonwealth Scientific and Industrial Organization (CSIRO) has conducted trials on intensively managed, short rotation bioenergy plantations grown on effluent, saline water, and sludge at Wagga Wagga, NSW (CSIRO FFP 2000). These plantations demonstrate potentially very short rotation times of 2-3 years for fuel reduction. Growth rates for selected eucalypts were shown to be around 15 tonnes per hectare per annum. A full-scale integrated wood processing plant is being built at Narrogin, Western Australia, by Western Power (RIRDC 2001). The demonstration plant will use planted mallee eucalyptus to produce eucalyptus oils, activated carbon, and renewable electricity. To date, approximately 9000 hectares of oil mallee have been planted, and this is set to increase when the Narrogin plant comes online. Also, GreenEco has a long-term target of $1000 \mathrm{MW}$ of capacity from crop-based resources producing $1800 \mathrm{GWhr} / \mathrm{yr}$. The target will be achieved by utilizing a combination of crop wastes or crops grown specifically for electricity production (Redding Energy Management 1999).

In Australia, some 237 million hectares (Mha) of land can potentially be used for producing additional biomass feedstock. Of the area, 132 Mha is not suitable because of 
the difficult terrain. Soil quality reduces the total down to 77 Mha, of which 51 million has already been utilized (Stewart et al. 1979 \& 1982), leaving just over 26 Mha available for new developments, which is relatively small (Foran and Mardon 1999). The challenge is therefore to select, or develop, suitable species, which grow well in the medium-to-low rainfall areas and produce good yields.

Although energy crops are expected to be a more expensive resource than forestry and wood wastes and are yet to be proven worldwide as a commercially viable resource, energy crops are expected to make a substantial contribution to meeting the federal government's $2 \%$ subsequent renewable target.

\section{Crop Waste}

There is theoretically a very large resource of crop wastes available in the form of straw and stubble from broadacre cropping. For example, in NSW alone there are $200,000 \mathrm{t} /$ year cotton trash and 300,000 t/year of rice hull (Burnard 2002). RIRDC has estimated that the potential in-field agricultural resources are around $55 \mathrm{Mt}$ (RIRDC 2002b). Besides nearly $20 \mathrm{Mt}$ bagasse and cane waste, there is $35 \mathrm{Mt}$ crop wastes per year. However, the availability of the resource is still uncertain. There is doubt that collection of the resource is viable, not only because of the associated cost or the need in the field production cycle for cropping, but also because the resource may not be available in a collectible form. Currently, this resource is only used commercially for generating biogas, primarily through projects under Sustainable Energy Development Authority (SEDA) of NSW (Burnard 2002). These include a cotton trash gasifier $(25,000$ t/year) at Auscott gin Narrabri, and a rice hull gasifier at Ricegrowers Co-operative Ltd (Sunrice).

\section{Wet Wastes from Agriculture and Food Processing}

This resource includes wastes from intensive animal production, the possibility of collecting waste from field animal production, and waste streams from processing of fruit and vegetables, grains, meat and meat products, beverages, and milk products. The potential resource from field animal production is theoretically large but it is doubtful that the field collection of the resource is practically viable. In total, the potential resource associated with wet wastes from agriculture and food processing could be of the order of $200 \mathrm{MW}$ (1,500GWh/year), made up of: $50 \mathrm{MW}$ from piggeries, a further $50 \mathrm{MW}$ from other animal husbandry, and $100 \mathrm{MW}$ from food processing wastes (Redding Energy Management 1999).

\section{Municipal Solid Wastes}

Municipal solid waste (MSW) generally refers to post consumer discards and spent and surplus materials, such as council collected garbage. It consists of approximately $60-70 \%$ biomass (lignocellulosic) originated materials and 30-40\% fossil based hydrocarbons. Additionally, the unwanted 'byproducts' of the productive/manufacturing sector (i.e., commercial and industrial, C\&I, wastes) and the residuals from the construction and demolition sector (C\&D) can also be included in MSW, since these wastes are usually disposed of in landfill. It has been reported that 8.7-13.5 Mt of MSW, $3 \mathrm{Mt}$ of C\&I, and 10.3 Mt of C\&D are annually generated nationwide (Glover 2002; 
Wootton 2002). Considering utilization of 30\% MSW and C\&I and 13\% C\&D, a total capacity of $930 \mathrm{MW}$ electricity may be potentially produced, which is equivalent to $2.2 \%$ of total installed capacity and 3.6\% total coal-fired installed capacity of Australia (Glover 2002). The potential capacity is sufficient to meet the federal government's $2 \%$ renewable electricity target.

\section{BIOMASS CHARACTERISTICS}

When used as a fuel for thermal chemical conversion process, biomass is generally characterized by conventional fuel analyses, including proximate analysis, ultimate analysis, ash analysis, heating value, etc. The characteristic data of typical Australian biomass species, including bagasse and cane trash, eucalyptus, and pine, used for electricity generation have been collected from the open literature (Sunshine electricity 2002; Gupta et al. 2002; DET CSIRO 2003). These are summarized in Table 2 compared with US biomass (Jenkins et al. 1998). Note that biomass composition varies from sample to sample even for same biomass species, such as bagasse, because of biomass resources varying in species, region, plantation, processing, and so on.

The compositions of main organic elements $(\mathrm{C}, \mathrm{H}, \mathrm{O})$ of Australian biomass are compared with those of international biomass in van Krevelen diagrams, shown in Figure 1. It can be seen that the organic compositions of Australian biomass are located in the composition range of international biomass. There also are no considerable differences between Australia's and overseas biomass in terms of other properties (see Table 2). However, a closer examination of Figure 1 reveals that the average $\mathrm{H} / \mathrm{O}$ ratio (i.e., obtained by dividing $\mathrm{H} / \mathrm{C}$ by $\mathrm{O} / \mathrm{C}$ ) for overseas biomass is about 2.28 while for the Australian biomass the $\mathrm{H} / \mathrm{O}$ ratio drops to about 2.07. This is an indication that, in general, the Australian biomass species (considering only lignocellulosic biomass) have slightly higher carbon contents, which make them quite attractive particularly for power generation applications.
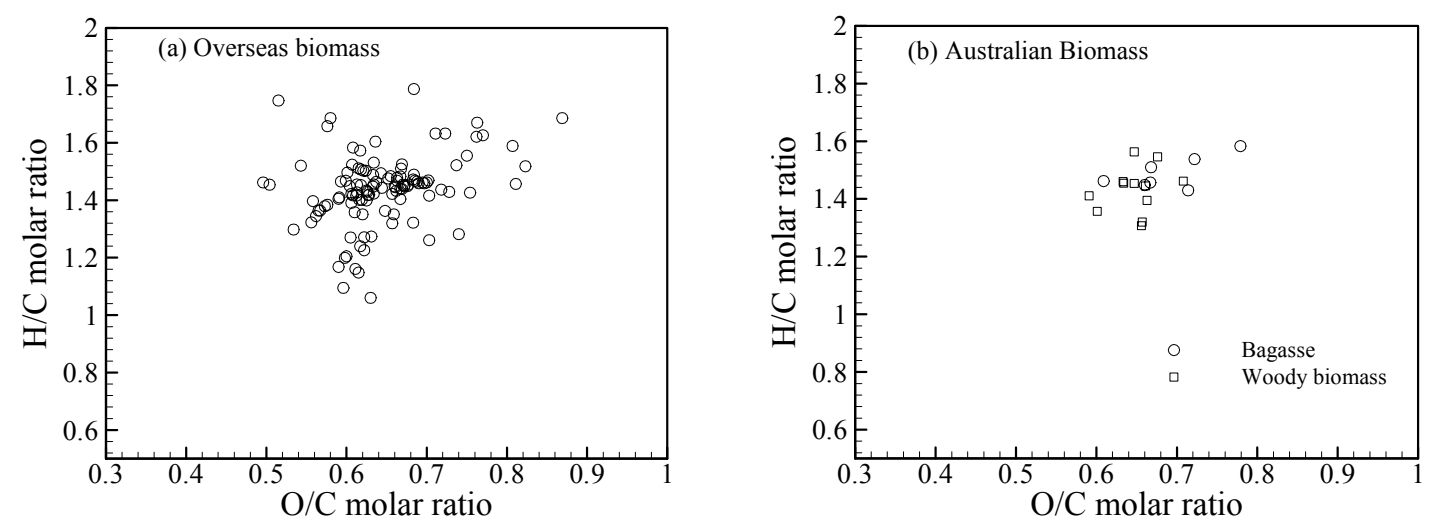

Figure 1. van Krevelen diagram for biomass materials (a) International biomass; (b) Australian biomass. 
Table 2. Characteristics of Biomass Materials

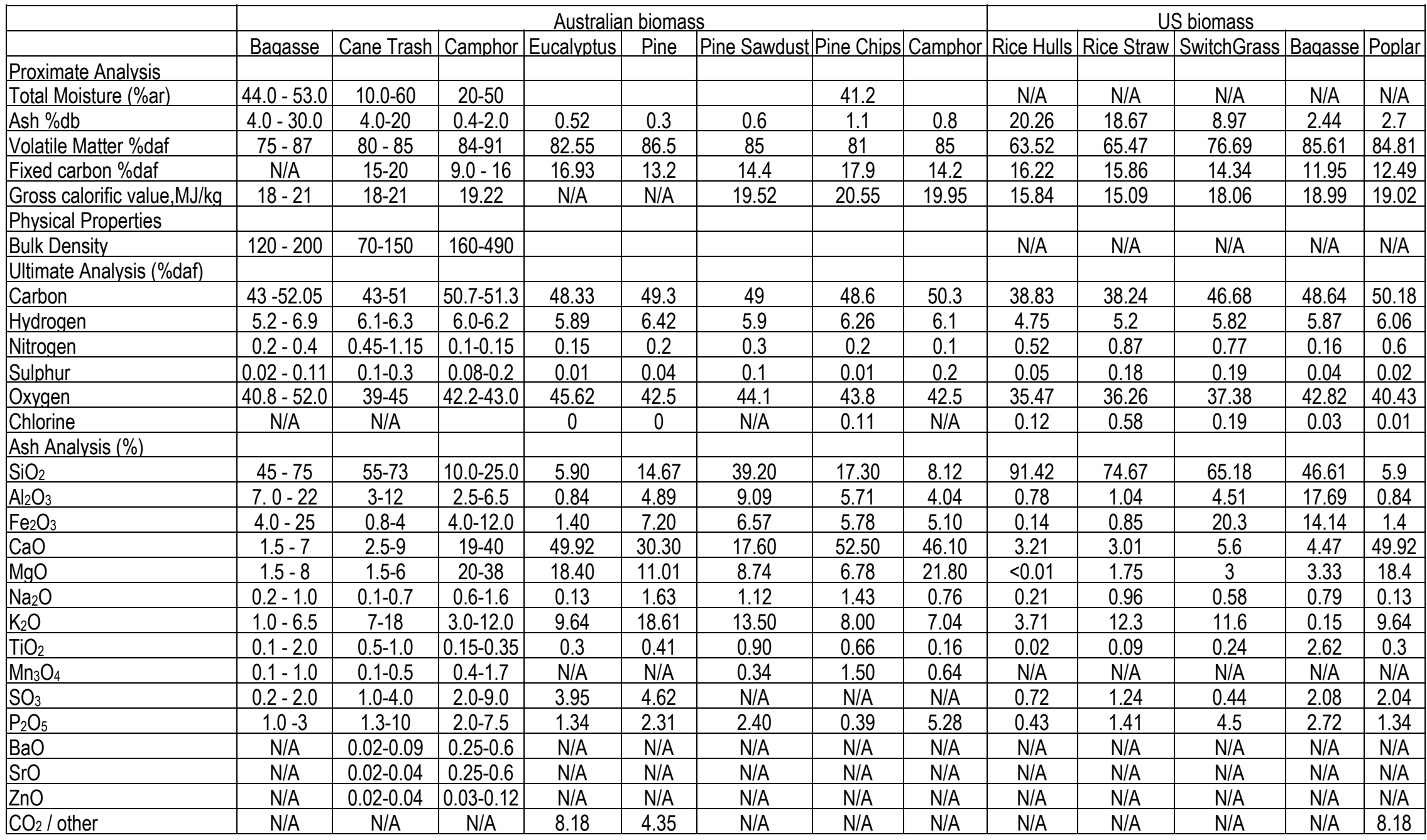




\section{BIOMASS UTILIZATION TECHNOLOGIES IN AUSTRALIA}

The conversion of biomass resources into useful energy services and products can be undertaken using a wide range of technological pathways. In Australia, various technologies for biomass utilization are being used or are under commercial development because of the availability of considerable existing and potential biomass resources. In particular, Australia has substantial experience in landfill gas, sewage gas, and bagasse power plants. Biomass utilization projects vary in scale from simple combustion in domestic open fires to fully commercial combined heat and power stations typically comprising complex $100 \mathrm{MWe}$ thermo-chemical reactors. The technical and commercial status of biomass utilization technologies together with other renewable energy technologies has been summarized in the Renewable Energy Action Agenda Discussion Paper (DITR 1999) and Renewable Energy Roadmap (DITR 2002). Based on bioenergy types produced from biomass, the technologies and their application are also summarized in Table 3. The recent developments on these technologies are discussed in more detail in the following sections.

Table 3. Status of Modern Biomass Utilization Technologies in Australia

\begin{tabular}{|c|c|c|c|c|}
\hline $\begin{array}{c}\text { Bioenergy } \\
\text { type }\end{array}$ & Technology & Biomass used & Status & $\begin{array}{c}\text { Application } \\
\text { examples }\end{array}$ \\
\hline \multirow[t]{4}{*}{ Electricity } & $\begin{array}{l}\text { Co-firing biomass and } \\
\text { coal }\end{array}$ & All biomass & $\begin{array}{l}\text { Mature and fully } \\
\text { commercial }\end{array}$ & $\begin{array}{l}\text { Macquarie } \\
\text { Generation and } \\
\text { Delta Electricity }\end{array}$ \\
\hline & $\begin{array}{l}\text { Direct combustion for } \\
\text { cogeneration electricity } \\
\text { and heat with } \\
\text { conventional boiler }\end{array}$ & $\begin{array}{l}\text { Bagasse (and cane } \\
\text { trash); wood wastes; } \\
\text { black liquor }\end{array}$ & $\begin{array}{l}\text { Mature and fully } \\
\text { commercial }\end{array}$ & $\begin{array}{l}\text { In sugar mills and } \\
\text { wood processing } \\
\text { plants (Sunshine } \\
\text { Electricity, 2002) }\end{array}$ \\
\hline & $\begin{array}{l}\text { Direct combustion in } \\
\text { Fluidized bed boiler }\end{array}$ & Green wastes & Mature and commercial & $\begin{array}{l}\text { EnviroStar (2003), } \\
\text { Energy Equip (2003) }\end{array}$ \\
\hline & $\begin{array}{l}\text { Biomass Integrated } \\
\text { Gasification Combined } \\
\text { Cycle }\end{array}$ & $\begin{array}{l}\text { Bagasse and cane } \\
\text { trash }\end{array}$ & $\begin{array}{l}\text { Research \& development, } \\
\text { demonstrating and pre- } \\
\text { commercial }\end{array}$ & $\begin{array}{l}\text { Sugar Research } \\
\text { Institute (Hobson } \\
\text { and Dixon 2002) }\end{array}$ \\
\hline \multicolumn{5}{|l|}{ Biogases } \\
\hline Landfill gas & Landfill/gas recovery & MSW & $\begin{array}{l}\text { Established and } \\
\text { commercial }\end{array}$ & $\begin{array}{l}\text { Energy Development } \\
\text { Limited, EDL, (2003) }\end{array}$ \\
\hline Sewage gas & Digestion & Sewage & $\begin{array}{l}\text { Mature and fully } \\
\text { commercial }\end{array}$ & $\begin{array}{l}\text { Malabar Sewage } \\
\text { Treatment Plant, } \\
\text { NSW (DITR 2000) }\end{array}$ \\
\hline Biogas & Digestion & $\begin{array}{l}\text { Wet wastes and food } \\
\text { wastes }\end{array}$ & $\begin{array}{l}\text { Digestor-commercial } \\
\text { demonstration }\end{array}$ & $\begin{array}{l}\text { EarthPower } \\
\text { Technologies } \\
\text { Sydney Pty Ltd }\end{array}$ \\
\hline Syngas & $\begin{array}{l}\text { Gasification for } \\
\text { producing syngas }\end{array}$ & $\begin{array}{l}\text { Crop wastes (cotton } \\
\text { trash and rice hull) }\end{array}$ & $\begin{array}{l}\text { Transition between R\&D } \\
\text { and commercialization }\end{array}$ & $\begin{array}{l}\text { Methanex Pty Ltd } \\
5,000 \text { t/y Syngas } \\
\text { Factory in Darwin }\end{array}$ \\
\hline \multicolumn{5}{|l|}{ Biofuels } \\
\hline Bio-ethanol & $\begin{array}{l}\text { Hydrolysis/Fermentation } \\
\text { / distillation }\end{array}$ & $\begin{array}{l}\text { Sugar, Molasses, } \\
\text { starch cellulose, } \\
\text { wood }\end{array}$ & $\begin{array}{l}\text { Established Commercial } \\
\text { with subsidy. Ethanol } \\
\text { exempt from fuel excise } \\
\text { to encourage production }\end{array}$ & $\begin{array}{l}\text { Various companies, } \\
\text { see Burnard (2002) } \\
\text { for a complete list. }\end{array}$ \\
\hline Bio-oil & Pyrolysis, gasification & $\begin{array}{l}\text { MSW, wood waste } \\
\text { (mallee) }\end{array}$ & $\begin{array}{l}\text { Established and } \\
\text { demonstration for }\end{array}$ & $\begin{array}{l}\text { Western Power (see } \\
\text { RIRDC 2002a }\end{array}$ \\
\hline
\end{tabular}




\begin{tabular}{|l|l|l|l|l} 
& & & $\begin{array}{l}\text { Commercialization } \\
\text { Bio-methanol }\end{array}$ & $\begin{array}{l}\text { report), } \\
\text { SWERF (see } \\
\text { Wooton 2002 for } \\
\text { more details) }\end{array}$ \\
\hline $\begin{array}{l}\text { Various } \\
\text { organizations and } \\
\text { companies, see } \\
\text { RIRDC (2002a) } \\
\text { report for more } \\
\text { details }\end{array}$ \\
\hline
\end{tabular}

\section{Electricity and Heat}

As summarized in Table 3, within the Australian context there are four potential technologies for utilizing biomass as fuel to generate electricity and heat (i.e., processing heat). Biomass can be used: (1) through direct combustion in conventional steam boiler to cogenerate processing steam and electricity, (2) through cofiring coal and biomass in a pulverized coal-fired boiler, (3) through directly combusting in a fluidized bed combustor (FBC), or (4) through gasification in a gasifier to produce low calorific value gas for running a gas turbine / generator for electricity generation. The biogases produced from biomass (see Table 3), can also be burnt or cofired with other fuels in boilers or gas engines further to generate electricity and heat, but which is described separately in the following biogas section.

Direct Combustion. Direct combustion is a commercialized technology, which is widely used to generate electricity and/or processing heat for processes of the industries related to the biomass resources, such sugar industry and wood products industry. In these cases, the biomass resources are generally available on-site and burned in conventional steam boilers. Bagasse has been extensively used as main fuel to generate electricity and heat in sugar mills of New South Wales and Queensland (Redding Energy Management 1999). Most sugarcane mills utilize bagasse to cogenerate steam and electricity for their own needs, but recently some plants have been expanded and upgraded to allow the exportation of large quantities of electricity to the grid. New relatively large cogeneration plants have been also established recently. Examples include: cogeneration projects of Condong Sugar Mill (30 MW) and Broadwater Sugar Mill (38 MW) in NSW (Sunshine Electricity 2002; Burnard 2002) and Rocky Point Sugar mill in QLD (Burbidge 2000) where sugarcane (both bagasse and cane trash) is utilized as the base fuel and other locally available biomass fuels (e.g., wastes from Camphor Laurel and saw mill residues) as supplement fuels.

The Australian bagasse cogeneration industry is already quite well developed. Benefits to the reduction of greenhouse gas and to generation of a second revenue stream for the sugar industry imply a significantly potential role of cogeneration in the electricity market (Dixon 2000). The $2 \%$ renewable measure is evolving as the primary driver for the development of cogeneration projects in the sugar industry.

Technologies are essentially the same for other biomass fuels, such as wood wastes including bark, chips, sawdust, mill sludge, fiber and scrap timber, which are used to generate processing steam and electricity in the timber product industry (Allsopp 2002). Australia has a great deal of experience in designing and building such plants. 
Co-firing. Co-firing biomass and coal in an existing pulverized coal-fired power plant is a low cost option to reduce greenhouse gas emissions by partly substituting coal with $\mathrm{CO}_{2}$ neutral biomass fuels. High combustion efficiency can be achieved with only minor or no modification to existing systems. It has been demonstrated that up to $15 \%$ of total energy output can be substituted from biomass fuel sources. In Australia, the Renewable Energy (Electricity) Act 2000 (ORER 2000) is the major driver behind electricity generation companies to adopt the practice of coal/biomass cofiring. In August 1999, Macquarie Generation's Liddell Power Station became the first coal-fired power station in Australia licensed to carry out cofiring for electricity production (Macquarie Generation 1999) with the aim of generating 2\% of energy through the burning of renewable biomass. The cofiring program was then expended to the company's Bayswater power station. The biomass supplied for Macquarie Generation's co-firing program includes sawdust and shavings from saw mills, forest thinnings, and laminate and MDF plant wastes. The $2 \%$ of energy output translates to $5 \%$ of biomass fuel by mass because of the lower calorific value of the biomass fuel compared to Australian black coal. At full capacity, the two stations consume about 900,000 tonnes per annum of biomass fuel. Other electricity generators are also burning biomass fuels. For example, Delta Electricity is cofiring biomass in its plants, aimed at reducing greenhouse emissions by up to 20,000 tonnes each year (Delta Electricity 1999). Other examples include CS Energy in the state of Queensland and Western Power in the state of Western Australia. The sources of biomass fuel for these companies include saw mill residues (a by-product of sustainable plantation operations), construction and demolition wood wastes, as well as urban green waste (UGW). Despite some technical difficulties, the cofiring technology appears to be fully adopted as a full-scale commercial operation by the electricity generation sector.

Fluidized Bed Combustion. A fluidized bed combustor (FBC) utilizes biomass fuels also through direct combustion. FBC involves the combustion of waste in a fluidized bed of sandy material with high thermal inertia but low combustion temperature. This form of combustion is highly tolerant to low heating value wastes with variable quality, and produces much lower pollutant emissions than other conventional forms of combustion (e.g., the low combustion temperature results in low thermal NOx production). Several green waste to energy projects are under way, using FBC technology of Energy Equipment Australia (EEA, 2003), including those in Nowra (18 MWt) of NSW, Bell Bay (65 MWt) of Tasmania, Kemerton (65 MWt) of Western Australia, Gold Costal (65 MWt) of Queensland and Morwell (65 MWt) of Victoria. For example, the energy facility being constructed in Stapylton, Gold Costal, Queensland (Stapylton Green Power Plant) by EnviroStar Energy Ltd., uses bubbling FBC technology which is fueled by UGW collected by urban councils within the greater Brisbane region. The first stage is 5 MWe and the second stage is $20 \mathrm{MWe}$. Approximately 240,000 tonnes of UGW will be converted into $145 \mathrm{GWh}$ of green power annually using $\mathrm{FBC}$ and steam turbine (EnviroStar Energy, 2002). A similar plant (20 MWe) will be also built in Morwell, La Trobe Valley, Victoria, which will be fueled by household green wastes as well as sawmilling residues from plantation timbers (EnviroStar Energy, 2002).

Biomass Integrated Gasification Combined Cycle (BIGCC). BIGCC is an advanced technology for utilizing biomass to generate electricity, in which biomass is 
gasified with air to produce syngas, which is then combusted to drive a gas turbine / generator for production of electricity. The residual heat of exhaust gas from the gas turbine is also used to produce steam and run a steam turbine / generator to generate more electricity. The combined cycle insures a very high energy efficiency. A 5 Mwe BIGCC system fueled by bagasse and cane trash is under development for a commercial scale demonstration plant in Queensland (Hobson and Dixon 2002).

\section{Biogas}

Biogas generation technologies include biochemical technologies such as anaerobic digestion, which breaks down organic material into methane and carbon dioxide, and thermal/chemical technologies such as pyrolysis and gasification, which converts biomass wastes into syngas and/or other products.

Landfill Gas Technology. Landfill gas technology is commercialized technology in Australia for generation of low calorific gas from landfilled MSW. Landfill gas is generated by the anaerobic decomposition of organic refuse deposited in landfills. It is primarily a mixture of carbon dioxide and methane in roughly equal proportions. Small quantities of water vapor and minor organic compounds are also present in the landfill gas. The substantial methane content of landfill gas enables it to be utilized as a fuel for power generation. Typically, generation of landfill gas begins within weeks of the organic MSW being deposited at a landfill site and continues at a gradually decreasing rate for over twenty years after filling ceases.

The commercial utilization of landfill gas as a fuel requires the gas to be extracted from landfill sites with a reasonably consistent flow and quality. In Australia, Energy Developments Ltd (EDL 2003) has developed a process that meets this requirement by drilling a pattern of vertical gas production wells across the landfill area. These wells are linked by an underground piping network to a central gas collection facility. The entire system is maintained under a vacuum, inducing the flow of landfill gas into the collection facility, where gas processing is undertaken to reduce moisture levels and filter out fine particles. The processed landfill gas is then used as a fuel in either gas engine or gas turbine generator sets. The power generation facilities are interconnected with a utility grid to enable the sale of electricity produced. The installed capacity for landfill gas in Australia was reported about $80 \mathrm{MW}$ at the end of 1997 (39 MW in Victoria, $13 \mathrm{MW}$ in WA, $12 \mathrm{MW}$ in SA, $13 \mathrm{MW}$ in NSW and $1 \mathrm{MW}$ in Queensland) and increased to $100 \mathrm{MW}$ by 2000 . The installed capacity of landfill gas is expected to steadily grow to about 250 MW by 2010 (Redding Energy Management 1999).

Anaerobic digestion. Anaerobic digestion technology is being demonstrated in Australia mainly to convert sewage and wet wastes from agriculture and food processing into biogas. In Australia, the amount of sewage feedstock for biogas production using the anaerobic digestion technology is relatively small, although the electricity production from this source has potential for expansion from its current level of $20 \mathrm{GWh} /$ year to an upper limit of about $200 \mathrm{GWh} /$ year. The Malabar Sewage Treatment plant in NSW now generates $3 \mathrm{MW}$ of electricity from digester gas (DITR 1999). The wet wastes are potentially a larger resource. For example, over $100 \mathrm{MW}$ of power for use in NSW can be produced from biogas generated from wet waste sources. Projects, such as Orange City 
Beef Biogas Plant under SEDA (Bartle 2002), have been developed to generate biogas from the wet wastes for firing boilers for cogeneration.

Gasification. Gasification technology is being demonstrated and commercialized in Australia mainly to gasify agricultural wastes into biogas. In NSW, two projects are under development, one for gasification of cotton trash and the other for gasification of rice hull to produce biogas (Bartle 2002). One project is developed using a technology (i.e., swept-drum pyrolyser and char gasifier) from Biomass Energy System Technologies (BEST) to convert cotton trash into syngas, which is aimed at 200,000 t/year cotton trash mostly in NSW. The first stage of the project is to replace LPG gas in ginning season $(8,500$ tones, $2,200 \mathrm{~h} / \mathrm{yr})$ and the second stage is to develop $2.5 \mathrm{MW}$ cogeneration system together with cotton trash collection and storage (25,000 tonnes, 8,000 h/yr). In another project, the same gasification technology is applied for utilizing 300,000 t/year of NSW rice hull to generate syngas. Gasification technology is quite well established and current operations do not face any safety related challenges.

\section{Biofuels}

In Australia, generating biofuels (Bio-oil, biodiesel, bioethanol, and biomethanol) from biomass, particularly from planted wood, is claimed to offer several advantages on a broad national scale. These include (ABA 1999; RIRDC 2002a):

- Environmental benefits (reduced greenhouse emissions, reduced vehicle exhaust emissions, improved urban-air quality, salinity abatement, improved soil stability and fertility and weed control)

- Economic benefits (related to the opportunities to provide viable economic alternatives to existing agricultural/forestry industries)

- Regional benefits (The majority of biomass resources are located in rural and regional Australia and their development could be expected to provide a major economic, employment and social stimulus to these areas.)

Therefore, biofuels have been attracting attention from the government and industries. Several R\&D and demonstration projects have been conducted recently in Australia.

Ethanol $\left(\mathrm{CH}_{3} \mathrm{CH}_{2} \mathrm{OH}\right)$. Bio-ethanol, a renewable fuel, is known as an "oxygenate" because it contains 37\% oxygen by weight (Klass 1998). Oxygen enhances the combustion of petrol in engines, and therefore contributes to reductions in exhaust emissions such as carbon monoxide. Ethanol is currently the most widely used biofuel in the transport sector in Australia (38\% ethanol production in 2000 used as transport fuel, the other $30 \%$ and $28 \%$ used as chemical in industry and for export, respectively) (Naughten 2001). Commercial sales of ethanol to the transport sector commenced in 1992, and sales of the 10\% ethanol/petrol blend fuel (E10) were expected to comprise 7\% of annual petrol usage by the NSW/ACT vehicle transport fleet by the end of 2000 . The Commonwealth Government is providing significant specific support for the development of ethanol as a transport fuel. In addition to providing an excise exemption for ethanol of 44 cents/lit, the Commonwealth and New South Wales Governments are currently supporting the development of new technologies to convert lignocellulose (woody waste products) into ethanol.

Ethanol is alcohol produced commonly from fermentation of sugar, using yeasts or other microorganisms to convert sugars into ethanol with $\mathrm{CO}_{2}$ as a by-product. There 
is little difference between the processes in fermentations for potable alcohol (beers, wines) and those for industrial or fuel grade ethanol. The feed for all ethanol fermentations is sugar, such as the sugars present naturally in sugarcane. In Queensland, ethanol is already made from molasses, a low-value, sugar-containing by-product of crystal sugar manufacturing.

In Australia, fuel ethanol research and trials on the production from biomass have been undertaken intermittently over the past twenty-five years. Previously, ethanol was produced mainly from molasses, a by-product of sugar industry (Naughten 2001; ABA 2003). Recently, fuel ethanol is produced as part of the value-added processing of wheat starch by Manildra Energy Australia Pty Ltd. at its plant at Nowra, NSW (Burnard 2003), which decreased the share of sugarcane based ethanol to $56 \%$ (of total 113 million litres ethanol) in 2000 and 63\% (of total 173 million litres) in 2001 (Naughten 2001). Using wheat starch as feedstock in Western NSW, the Manildra plant will have the capacity to produce up to 700 million litres of blended ethanol fuel annually. According to industry estimates, use of this fuel could reduce transport emissions by up to 7 per cent in NSW and the Australian Capital Territory (ACT). The plant has sourced wheat from farms in Western NSW, milled at the company's Manildra plant. It incorporates two technological innovations developed and proven in an existing pilot plant. These are Manildra's continuous fermentation technology and a molecular sieve dehydration system; both will deliver significant energy and cost efficiencies. The project represents a major advance in the commercialization of ethanol fuel in Australia in terms of meeting current and future demands for renewable transport fuel.

Sugarcane and wheat are food crops. Their use for ethanol production is limited by their costs as human and animal feeds, and it is typically the by-products of the manufacture of food grade products that are used for ethanol production. Therefore, the cost of ethanol from these materials is higher, mostly because of the cost of the feedstock. Biomass, in the form of wood and agricultural residues, is viewed as a low cost alternative feed to sugar and starch. However, only part of the biomass (cellulose and hemicellulose) can be converted into sugar using the fermentation process. Nevertheless, because it is potentially available in far greater quantities than sugar and starch feeds, it receives significant attention as a feed material for ethanol production. Technical and economic research related to ethanol production from wood plantation materials (Foran and Marden 1999; RIRDC 2002a) has been carried out in Australia.

Biodiesel. Biodiesel is the name for a variety of ester-based oxygenated fuels made from vegetable oils or animal fats (Klass 1998). Vegetable and animal oils and fats, like soybean, rapeseed/canola, recovered vegetable and animal fats, can be used to produce biodiesel. Biodiesel is the only alternative fuel that can be used directly in any existing, unmodified diesel engine. Because it has similar properties to petroleum diesel fuel, biodiesel can be blended in any ratio with petroleum diesel fuel. Biodiesel has many advantages as a transport fuel. For example, biodiesel can be produced from domestically grown oilseed plants such as canola. Producing biodiesel from domestic crops reduces Australia's dependence on foreign petroleum, increases agricultural revenue, and creates jobs.

The production of biodiesel is well known and carried out using a series of catalytic reactions. There are a small number of outlets providing biodiesel currently in 
Australia. There are also quite a number of companies around Australia in the planning stages or nearing completion of their biodiesel production facilities (BAA 2003). A biodiesel pilot plant, using acid esterification, glycerine recovery technologies to generate up to $10 \mathrm{ML} /$ year was recently developed under the administration of SEDA (Burnard 2002).

Bio-oil. Bio-oil refers to the oils, including benzene and toluene derived either from biomass directly by pyrolysis or indirectly by separating/processing tar compounds formed during biomass gasification. In Australia, bio-oil technology is undergoing commercialization. For example, EDL has been demonstrating a technology called Solid Waste to Energy \& Recycling Facility (SWERF®) (Wooton 2002), which integrates waste to energy and recycling processes and uses advanced thermal conversion to convert waste into useful energy forms including electricity and bio-oil. The waste material used is mainly MSW and also includes waste biomass and commercial and industrial waste. The SWERF® process steps are as follows (Wooton 2002):

- Sterilisation and pulping of the waste in a rotating pressurized autoclave.

- Materials separation to recover recyclable materials.

- Washing of the "pulp" to remove dirt, sand and glass fragments.

- Drying of the pulp in a pressurized flash drying device.

- Gasification of the pulp to produce Syngas, and/or Bio-oil.

- Generation of electricity from Syngas and/or sale of Bio-oil as refinery or petrochemical.

It is reported that in Bio-oil mode, SWERF® generates about $130 \mathrm{~kg}$ of bio-oil together with approximately $300 \mathrm{kWh}$ of electricity for each tonne of municipal solid waste (MSW) processed.

Pilot-scale studies on an integrated oil mallee processing and electricity cogeneration plan is underway in Western Australia (RIRDC 2001), which is aimed at cogenerating mallee oil, activated carbon, and electricity.

Methanol $\left(\mathrm{CH}_{3} \mathrm{OH}\right)$. In addition to ethanol, the other well known oxygenate fuel is methanol (Klass 1998). It is also one of the most commonly used chemicals in the world today. Methanol has been used as the feedstock for the production of methyl tertiary butyl ether (MTBE), a widely used additive to boost octane levels in petrol (RIRDC 2002a). In 1997, 27\% of the world's methanol production was used to make MTBE. However, recent problems with contamination of groundwater by MTBE in the USA have led to reductions in its use and expanded production of ethanol as an alternative oxygenate for petrol. Methanol can also be used in fuel cells. Commercial production of methanol is from synthesis gas (a mixture of $\mathrm{H}_{2}$ and $\mathrm{CO}$ ) by a catalytic process. Now almost all the methanol used world-wide come from the processing of natural gas.

Methanol can also be derived from biomass. Modern methods proposed for the production of methanol from biomass involve the conversion of the biomass to a suitable synthesis gas through gasification and pyrolysis, after which the processing steps are very similar to those developed for methanol from natural gas. There is adequate technology available for all stages except for gasification. The production of synthesis gas by gasifying biomass, such as wood, straw, bagasse, has yet to be demonstrated in a largescale plant but it has been implemented in small demonstration plants overseas. 
Technologies such as the Institute of Gas Technology pressurised direct oxygen fired gasification and the Battelle-Columbus indirect gasification have been used for biomass gasification (RIRDC 2002a). There is no commercial or demonstration unit of methanol from biomass, although there are many research projects concerning production of methanol from biomass (e.g. Hamelinck and Faaij 2002; Dong and Steinberg 1997; Borgwardt 1997).

Nevertheless, there are several studies reported in Australia (Stewart et al. 1979, 1982; Foran and Mardon 1999; RIRDC 2002a) detailing technical and economic analysis of generating methanol from biomass, particularly from wood. In addition, prospects for an Australian economy based on ethanol and methanol fuels have been considered (Foran and Mardon 1999). The major conclusions from the research are:

1. Australia has land for biomass feedstock production. There is potential to generate 14.4 Mt of methanol and 4.4 Mt of ethanol per annum according to the estimation of Stewart et al. $(1979,1982)$.

2. Research has focused on a number of linked problems in Australian farming lands, such as dryland salinity. This has led to wide-scale research and development of deep-rooted plant production systems, in particular, the oil mallee production system, such as in the wheat belt of Western Australia (RIRDC 2001). Biomass yields of 5 tonnes per hectare dry matter per year are feasible and, with spaced planting of $20 \%$ of total land area of wheat belt, 15 million dry tonnes would be available per annum. It is estimated that control of the dryland salinity problem may require a landscape cover of $80 \%$, and this potentially could produce 75 million tonnes per annum, enough to make the Western Australian State self-sufficient in liquid fuels and allow for some export (RIRDC 2001).

3. Methanol is estimated to cost 62 cents per litre in a 390 ML plant built today in Australia using the world's best technology (RIRDC 2002a), where 1.34 Mt fresh biomass is required annually. The assumed cost of the delivered raw material is $\$ 30$ per tonne of fresh woody biomass. The price depends on plant size (RIRDC 2002a; Foran and Mardon 1999) and raw material price (Foran and Mardon 1999). Using high price raw material (164 \$/tones on dry weight) and assuming a relatively small plant (100,000 tonnes methanol per annum, i.e., 127 ML per annum, and 0.26 Mt dry biomass used), Foran and Mardon (1999) estimated a price of 81 cents per litre for methanol. Using the same price of raw material and considering 50\% moisture content of fresh biomass, the price of methanol is estimated to be 64 cents per litre, consistent with the results of the RIRDC study (2002a). A decrease in the price may be possible due to some improvements to technology over the next fifteen years. Nevertheless, the cost gap between biomethanol and synthetic methanol is anticipated to exist until 2015. The methanol from biomass is estimated to cost 50 cent/litre versus the methanol from natural gas at $24 \mathrm{cent} /$ litre (RIRDC 2002a). The benefits to the environment (i.e., benefits related to reductions in production of greenhouse gases, valued at 9.5 cent/litre, and on-site benefits of salinity reduction, valued at 1.4 cent/litre) will further narrow the gap and achieve the best price of about 39 cent/litre) (RIRDC 2002a). 
4. Unlike the production of ethanol, the production of methanol from biomass is relatively insensitive to biomass quality or species (Foran and Mardon 1999) since the whole biomass substance is converted into carbon oxides, hydrogen, water, and so on. Table 4 presents the amount of biomass (dry weight) needed for generating one tonne of methanol. The amount varies depending on biomass moisture content.

Table 4. Quantities of Raw Biomass Material Used in Methanol Production (Foran and Mardon 1999)

\begin{tabular}{|llll|}
\hline Raw material & \% dry matter & \multicolumn{2}{l|}{$\begin{array}{l}\text { Dry weight of biomass (tones) for producing per } \\
\text { tones of methanol }\end{array}$} \\
\cline { 2 - 4 } & & Without pre-drying & With pre-drying \\
\hline Wood & 80 & 2.2 & $2.2+0.4$ \\
Wood & 50 & 3.0 & $2.3+0.4$ \\
Bagasse & 50 & 3.1 & $2.4+0.4$ \\
Sugarcane trash & 50 & 3.3 & \\
Cereal straw & 80 & 2.4 & \\
\hline
\end{tabular}

${ }^{*}$ Pre-drying materials of $50 \%$ dry matter requires 0.4 units of raw materials as fuel.

5. Compared to ethanol production, methanol is cheaper (Foran and Mardon 1999; RIRDC 2002a) since all biomass material is converted into methanol. Moreover, the capital costs of methanol plants are also lower, primarily because no acids are used in the processes so there is no need to construct the plant from more expensive acid-resistant materials.

Currently, there is no project in Australia considering methanol from biomass, either from an R\&D standpoint or as a production facility. This is despite the fact that all related technologies for the production are available. The reasons are the high price and lack of market interest. Ethanol can be blended into petrol as green fuel, whereas methanol cannot. If new applications and markets can be exploited, then there is potential for significant growth in the use of methanol, since it has a comparable price to ethanol but higher conversion efficiency. Possibilities include the use of methanol for generating clean fuels from coal. Methanol also might be considered for use in fuel cells.

\section{BIOMASS PRICES}

The prices of bioenergy from various technologies compared with the price of energy generated from fossil fuels are summarized in Table 5. As noted in the table, bioenergy is more expensive than conventional energy. However, because great environmental contributions can be made by biomass utilization (e.g., $\mathrm{CO}_{2}$ and dryland salinity reductions), a considerable decrease in bioenergy price can be achieved, should appropriate tax incentives become set in place (RIRDC 2002a). The social benefit, e.g., the contribution to the regional economy and employment, is also important but difficult to estimate. After considering the benefits of greenhouse abatement and on-farm salinity reduction, biomass electricity is cost competitive with conventional electricity (RIRDC 
2002a). The government promotions and community awareness also has lead bio-ethanol to be considered an acceptable transportation fuel in the Australian market.

Table 5. Cost of Bioenery Technologies Compared to Other Renewable Energy Technologies and Fossil Fuels - Current and Expected Trend (Redding Energy Management 1999)

\begin{tabular}{|c|c|c|c|c|}
\hline $\begin{array}{l}\text { Energy } \\
\text { source }\end{array}$ & Technology & $\begin{array}{c}\text { Cost, } \\
\text { \$/MWh }\end{array}$ & Expected trend & Comment \\
\hline Coal & Coal fired steam & $30-40$ & Stable & \\
\hline Gas & & $35-60$ & Small decrease & \\
\hline Wind & $\begin{array}{l}\text { Wind turbine/generator } \\
\text { Wind RAPS }\end{array}$ & $\begin{array}{l}75-90 \\
150-400\end{array}$ & $\begin{array}{l}\text { Decrease } 15-30 \text { by } \\
2010\end{array}$ & $\begin{array}{l}\text { Site (wind resource) variation } \\
\text { is reason for the range in } \\
\text { costs }\end{array}$ \\
\hline Hydro & $\begin{array}{l}\text { Hydro turbine/generator } \\
\text { Micro hydro RAPS }\end{array}$ & $\begin{array}{l}40-100 \\
70-250\end{array}$ & $\begin{array}{l}\text { Increase (attractive } \\
\text { site are used) } \\
\text { Remain constant }\end{array}$ & Cost is very site specific \\
\hline Fuel wood & $\begin{array}{l}\text { Boiler } \\
\text { Pyrolysis furnace }\end{array}$ & $\begin{array}{l}70-110 \\
0.45-0.85 \text { per } \\
\text { litre }\end{array}$ & & $\begin{array}{l}\text { Cost assumes biomass is } \\
\text { provided at a cost of } 20- \\
50 \$ / \text { tonnes }\end{array}$ \\
\hline Bagasse & $\begin{array}{l}\text { Boiler (cogeneration) } \\
\text { Gasification }\end{array}$ & $\begin{array}{l}50-60 \\
30-100[b]\end{array}$ & $\begin{array}{l}\text { Decrease expected } \\
\text { with efficient } \\
\text { increase }\end{array}$ & $\begin{array}{l}\text { Embedded generator network } \\
\text { cost savings }\end{array}$ \\
\hline $\begin{array}{l}\text { Various } \\
\text { wastes }\end{array}$ & $\begin{array}{l}\text { Boiler (cogeneration) } \\
\text { Gasifier/gas engine }\end{array}$ & $80-200[b]$ & $\begin{array}{l}\text { Decrease } 25 \% \text { by } \\
2010\end{array}$ & \\
\hline $\begin{array}{l}\text { Sugar, } \\
\text { starch } \\
\text { cellulose }\end{array}$ & $\begin{array}{l}\text { Hydrolysis/fermentation } \\
\text { /distillation }\end{array}$ & $\begin{array}{l}0.28-0.69 / \text { lit } \\
\text { ethanol }\end{array}$ & $\begin{array}{l}\text { Competitive with oil } \\
\text { by } 2010\end{array}$ & $\begin{array}{l}\text { Worldwide cost has } \\
\text { decreased } 50 \% \text { over past } 10 \\
\text { years }\end{array}$ \\
\hline Wet waste & $\begin{array}{l}\text { Biogas digestion/ } \\
\text { Gas engine }\end{array}$ & $30-200$ & $\begin{array}{l}\text { Increase beyond } \\
2005\end{array}$ & $\begin{array}{l}\text { Economics depend on } \\
\text { negative cost of fuel and } \\
\text { value of by-products }\end{array}$ \\
\hline $\begin{array}{l}\text { Landfill gas } \\
\text { Sewage } \\
\text { gas }\end{array}$ & Gas engine & $50-99$ & No change to 2010 & $\begin{array}{l}\text { Most of resource recoverable } \\
\text { at } 65 \$ / \mathrm{MWh}\end{array}$ \\
\hline
\end{tabular}

a. Unit is Australian \$/MWh except where other unit is specific

b. Estimated cost once technically viable

\section{SUITABILITY OF BIOMASS FOR LOCAL USE AND EXPORT}

In Australia biomass, comprising mainly bagasse and wood waste, is the dominant feedstock in the renewable energy consumption (Bush et al. 1997). Unlike other renewable energy sources (e.g., wind, solar, geothermal, etc.) biomass produces $\mathrm{CO}_{2}$ emissions when it is processed (e.g., combustion, gasification, etc.). Nevertheless, biomass is considered to be a $\mathrm{CO}_{2}$ neutral energy resource, because the carbon dioxide produced from biomass is absorbed by growing plants in a relatively short cycle. In Australia there is substantial land area for biomass production, and there are substantial biomass resources. Biomass utilization not only provides renewable energy and reduces 
greenhouse gas emission for sustainable energy development, but also benefits the sustainable agricultural and forestry industries. Therefore, much attention has been directed to it from governments, industries and communities.

On November 20, 1997, the Prime Minister announced a package of measures designed to address climate change, including measures aimed at reducing the impact of the energy sector on the environment in a document called "Safeguarding Our Future: Australia's Response to Climate Change." From then on, extensive initiatives were put forth for reducing the greenhouse gas emissions and utilizing renewable energy on both the supply and demand sides.

Renewable energy use is expected to expand significantly in Australia in the next decade. This is due to market forces and government initiatives. Perhaps the most important initiative is the Mandatory Renewable Energy Target (MRET) through the Renewable Energy (Electricity) Act 2000 and its Regulation (ORER 2000), which involves a mandatory target for electricity retailers and large electricity purchasers to source an additional $2 \%$ of their electricity from renewable energy sources by 2010 . This is equivalent to an extra 9,500 $\mathrm{GWh}$ per annum of electricity generated from renewable energy (ORER 2003). This regulation enables the biomass electricity to be costcompetitive in the electricity market.

Another important driver is the Renewable Energy Action Agenda (DITR 2002) initiated by the federal government in 1999. This entails renewable energy industry participants working with government, primarily through the Department of Industry Tourism and Resources and the Australian Greenhouse Office, to move the renewable energy industry to sustainable and international competitiveness with a target of annual sales of $\$ 4$ billion by 2010 . The industry participants have identified five overarching strategies to achieve this goal. These strategies relate to:

- Market Development

- Building Community Commitment

- Building Industry Capability

- Setting the Policy Framework

- Encouraging a Culture of Innovation.

The Renewable Energy Action Agenda (DITR 2000) launched by the then Minister for Industry, Science and Resources in June, 2000, identifies nine priority initiatives to implement the strategies. This agenda and the related "roadmap" (DITR 2002) include several initiatives aimed at promoting utilization of renewable energy, such as Initiative 2 "Promote the Development of the Renewable Transport Fuel Industry," and at promoting development of the domestic market and better exploitation of the export market for Australian renewable energy.

Additionally, state governments have also established a wide range of programs that can stimulate the development and uptake of sustainable energy technologies. These programs have been classified in the "Commonwealth and State Government Support to Sustainable Energy in Australia: an Overview"(AGO 2002) as:

- Programs that specifically target Renewable Energy.

- Programs that target overall greenhouse emissions abatement including through waste management, and energy efficiency. 
- Programs that support innovation in firms including in the field of Sustainable Energy.

Due to the significant role that biomass plays in the Australian renewable energy market, such programs are motivating biomass energy utilization and related technology research and development in Australia.

Another key driver of growth of the renewable energy industry will be the level of community awareness and commitment to the environment and the community's acceptance of renewable energy industry as a solution to environmental concerns regarding energy use (DITR 2000).

For consumers, Green Power schemes represent the first convenient means by which they can exercise choice over the source of their electricity and support the development of renewable energy. Green power schemes offer electricity customers the opportunity to support grid-connected renewable energy systems. However, the household connection to the Green Power schemes is very low (just over 3\% of Australian households, CSIRO 2000), compared with those in other parts of the world particularly in the Scandinavia (e.g. the uptake in Sweden is about 13\%, Bird et al. 2002). This relatively low uptake is likely to be significantly affected by the low level of consumer awareness. Almost $80 \%$ of households not connected to Green Power reported that they were not aware of the scheme.

In the Renewable Energy Action Agenda (DITR 2002), an initiative, Initiative 4 (Increase community commitment to renewable energy) focus primarily on the provision of independent, accurate information and other awareness raising activity to increase the community's commitment to renewable energy and Green Power. The government and industry will be jointly responsible for the implementation of the initiative through various activities. Additionally, technology improvement and contribution to environment protection and sustainable development will lead to the decrease of renewable energy price, thus acceptable to the community.

\section{SUMMARY}

- Bioenergy technology is extensively developed and commercially used in Australia. Australia has substantial experiences in cogeneration of electricity and heat from biomass material, particularly from bagasse, and also in landfill gas and sewage gas generation.

- For generation of biofuels from biomass, technology is under demonstration and commercialization for large-scale plants. Moreover, much attention is being put on bioethanol, driven by substituting petrol as renewable transportation fuels.

- In the case of bio-ethanol, there has been little technology development effort, due to a lack of market interest. However, technical and economic analysis indicated that methanol is at least economically equivalent to ethanol production and even higher conversion efficient because there is no limit on biomass raw material. If new markets can be exploited using bio-methanol, such as using methanol for clean coal and for fuel cells, then the prospect of bio-ethanol is bright. This is because methanol technology not only generates green energy, but also can promote biomass plantation. 
In this way bio-methanol has potential to significantly benefit sustainable energy, sustainable agriculture, the forestry industry, and rural economies.

\section{ACKNOWLEDGEMENTS}

The authors wish to acknowledge the assistance provided to them by Prof. Raj Gupta (University of Alberta, Canada), Mr. Steve Richarson (University of Newcastle), Dr. Emre Cetin (University of Sydney) and Dr. Vladimir Strezov (Macquarie University).

\section{REFERENCES CITED}

Allsopp, B. A. (2001). "Timber by-products as biomass fuels: materials handling issues," http://www.ghd.com.au/papers/

Australian Greenhouse Office (AGO) (2002). "Commonwealth and state government support to sustainable energy in Australia: An overview,"

http://www.greenhouse.gov.au/renewable/

Australian Greenhouse Office (AGO) (2003). "Renewable energy website," http://www.greenhouse.gov.au/renewablel

Australian Biofuels Association (ABA) (1999). "Multi-benefit of a national biofuel industry," Policy paper from the Australian Biofuel Association, http://www.australianbiofuelsassociation.org.au/

Bartle, J. (2002). "Achieving sustainability through bioenergy," Bioenergy Australia 2002 Conference, Sydney, NSW.

Bird, L., Wustenhagen, R., and Aabakken, J. (2002). "Green Power Marketing Abroad: Recent Experience and Trends," National Renewable Energy Laboratory Technical Report, NREL/TP-620-32155, USA.

Borgwardt, R. H. (1997). "Biomass and natural gas as co-feedstocks for production of fuel for fuel-cell vehicles," Biomass and Bioenergy 12, 333-345.

Burbidge, D. (2000). "Renewable energy boosts rural Queensland," Proceedings of Solar 2000 from Fossils to Protons, CD-ROM, (D. Mills, ed.), Australian and New Zealand Solar Society Conference, Brisbane, Nov 29 - Dec 1.

Burnard A. (2002). "Sustainable Energy Development Authority (SEDA), New bioenergy developments in New South Wales," Australian Bioenergy Conference 2002, Manly, NSW, 2-3 December.

Bush, S., Harris, J., and Ho Trieu, L. (1997). "Energy 1997 projections- Australian energy consumption and production," ABARE Research Report 97.2, Canberra.

CSIRO Forestry and Forest Products (2000). "The Wagga Wagga effluent plantation project," www.ffp.csiro.au/pffleffluent_guideline/.

Delta Electricity (1999). http://www.del.com.au/

Department of Industry, Tourism and Resources (DITR) (2000). "Renewable energy action agenda," June, http://www.industry.gov.au/

Department of Industry, Tourism and Resources (DITR) (1999). "Renewable energy action agenda discussion paper," December, http://www.industry.gov.au/ 
Department of Industry, Tourism and Resources (DITR) (2002). "Renewable energy roadmap," October, http://www.industry.gov.au/

DET (Division of Energy Technology) (2003). CSIRO, Australian Biomass Database, at http://www.det.csiro.au/.

Davidson, R. M. (1999). "Experience of Co-Firing Waste with Coal," International Energy Agency (IEA) Coal Research report, 1999.

Dickson, A., Thorpe, S., Harman, J., Donaldson, K., and Tedesco, L. (2001). (ABARE), "Australian energy outlook to 2019-20," Australian Institute of Energy, National Conference Energy 2001 - Exploring Australia's Energy Future, Sydney, 22-33 November.

Dong, Y., and Steinberg, M. (1997). "HYNOL - An economical process for methanol production from biomass and natural gas with reduced $\mathrm{CO}_{2}$ emission," International Journal of Hydrogen Energy, 22, 971-977.

Driscoll, D. A., Milkovits, G., and Freudenberger, D. (2000). Impact and use of firewood in Australia. CSIRO Sustainable Ecosystems report to Environment Australia.

Energy Development Ltd. (2003). http://www.edl.com.au/

EnviroStar Energy Ltd. (2002). http://www.envirostar.com.au/projects/.

Energy Equipment Australia (2003). http://www.energyequipment.com.au/

Energy Research and Development Corporation (ERDC). (1994). "Biomass in the energy cycle study," ERDC 94/234, Canberra, Australia.

Foran, B., and Mardon, C. (1999). "Beyond 2025: Transition to the bio-alcohol economy using ethanol and methanol," Report to National Dryland Salinity Program of the Land and Water Resources Research and Development Corporation, December.

Gupta, R. P., Beacher, C., Bhargava, A., and Wall, T. F. (2002). "The fate of inorganic matter in biomass during combustion," Pittsburgh Coal Conference.

Hamelinck, C. N. and Faaij, A. P. C. (2002). "Future prospects for production of methanol and hydrogen from biomass," Journal of Power Source 111, 1-22.

Hobson, P. A., and Dixon, T. F. (2002). "Gasification technology development for the sugar industry in Queensland," Bioenergy Australia 2002 Conference, Sydney, NSW, 2-3 December.

Jenkins, B. M., Baxter, L. L., Miles, T. R., Jr., and Miles, T. R. (1998). “Combustion properties of biomass," Fuel Processing Technology 54, 17-46.

Klass, D.L. (1998). “Biomass for Renewable Energy, Fuels, and Chemicals,” Academic Press, San Diego, USA, ISBN: 0124109500.

Macquarie Generation (1999). http://www.macgen.com.au/

Glover, M. (2002). "The application of urban waste streams for sustainable energy recovery," Bioenergy Australian 2002 Conference, Sydney, NSW, 2 -3 December.

Naughten, D. (2001). "Viability of sugar cane based fuel ethanol," ABARE Report to $A F F A$, Canberra, Australia, October.

Office of the Renewable Energy Regulator (ORER) (2000). Renewable Energy (Electricity) Act, No.170, 2000, at http://www.orer.gov.au/

Redding Energy Management (1999). "2\% renewables target in power supplies potential for Australian capacity to expend to meeting the target," Report to Australian Greenhouse Office, January, www.greenhouse.gov.au

Renewable Energy (Electricity) Act 2000 (2000). www.orer.gov.au 
RIRDC (Rural Industries Research \& Development Corporation) (2002a). Wood for Alcohol Fuels, Status of Technology and Cost/Benefit Analysis of Farm Forestry for Bioenergy," RIRDC Publication No.02/141, Barton ACT: Rural Industries Research and Development Corporation, November 2002.

RIRDC (Rural Industries Research \& Development Corporation) (2002b). Biomass Atlas of Australia, RIRDC Publication No.02/137, November 2002.

RIRDC (Rural Industries Research \& Development Corporation) (2002c). Agroforestry and Farm Forestry, A Report for Joint Venture Agroforestry Program, RIRDC Publication No.02/63, June 2002.

RIRDC (Rural Industries Research \& Development Corporation) (2001). Integrated Tree Processing of Malle Eucalypts, A Report for Joint Venture Agroforestry Program by Enecon Pty Ltd, RIRDC Publication No.01/160, November 2001.

Sami, M., Anamalai, K., and Wooldridge, M. (2000), "Cofiring of Coal and Biomass Fuel Blends," Progress in Energy and Combustion Science 27, 171-214.

Stewart, G. A., Gartside, G., Gifford, R. M., Nix H. A., Rawlins, W. H. M., and Siemon, J. R. (1979). The potential for liquid fuels from agriculture and forestry in Australia, CSIRO.

Stewart, G. A., Hawker, J. S., Nix, H. A., Rawlins, W. H. M., and Williams, L. R. (1982). The potential for production of 'hydrocarbon' fuels from crops in Australia, CSIRO.

Sunshine Electricity (2002). Broadwater Biomass Cogeneration Proposal, Environmental Impact Statement, February 2002.

Werther, J., Saenger, M., Hartge, E. U., Ogada, T., and Siagi, Z. (2000). "Combustion of Agricultural Residues," Progress in Energy and Combustion Science 26, 1-27.

Williams, A., Pourkashanian, M., and Jones, J. M. (2001). "Combustion of Pulverised Coal and Biomass," Progress in Energy and Combustion Science 27, 587-610.

Wootton, P. (2002). "Development of SWERF® technology," Bioenergy Australia 2002 Conference, Sydney, NSW, 2-3 December.

Yainshet, A., Nelson, R., and Love, G. (2002). "Rising domestic plantation wood supplies - Implications for Australian production and use of forest products," ABARE Current Issues, 02.7., August 2002, at: http://www.abareconomics.com/

Article submitted: June 2, 2006; Revision accepted: July 23, 2006; Published August 1, 2006 